\title{
Multiple granular cell tumor of the colon
}

A 44-year-old man was referred to our endoscopy unit because of a family history of colorectal neoplasia. Colonoscopy revealed numerous semi-pedunculated polyps with intact mucosa, measuring 6-12 mm, in the cecum ( $n=2)$, ascending $(n=5)$, and transverse $(n=2)$ colon. The two largest polyps, measuring $8 \mathrm{~mm}$ and $12 \mathrm{~mm}$, respectively, and occurring in the ascending colon ( $\bullet$ Fig. 1 ), were removed by snare polypectomy. Histologic examination of the polyps revealed a submucosal tumor composed of cells with small round nuclei and abundant granular eosinophilic cytoplasm ( $\bullet$ Fig. 2). Immunohistochemical analysis showed the tumor cells expressed S-100 protein ( $\bullet$ Fig. 3 ). The resected polyps were diagnosed as granular cell tumor (GCT). Upper endoscopy, enteroscopy by videocapsule, and abdominal computed tomography scan were unremarkable. The patient entered an annual endoscopic follow-up program. GCT is a rare tumor that may occur in any site of the body [1,2]. It commonly occurs in the oral cavity, the skin, and the subcutaneous tissue, and is seldom found in the gastrointestinal tract $[1,2]$. In the gastrointestinal tract, the most common site is the esophagus, followed by the large intestine [1,2]. Gastrointestinal GCT is usually found incidentally during endoscopy as a submucosal tumor and is multiple in $10 \%-20 \%$ of all cases (15 patients described in the literature) [2].

The final diagnosis of GCT depends on pathologic findings: cells with small, uniform nuclei and abundant granular eosinophilic cytoplasm containing acidophilic, periodic acid-Schiff (PAS)-positive, diastase-resistant granules, and expression of S-100 protein or neuron-specific enolase $[1,2]$.

GCT is usually clinically and histologically benign, with only a few malignant GCT cases reported [1,2]. Malignant behavior is suggested by large size $(>4 \mathrm{~cm})$, rapid growth, and invasion of the adjacent tissues rather than the histologic features $[1,2]$. As gastrointestinal GCTs are considered benign, a conservative approach is suggested by means of endoscopic resection and a strict endoscopic follow-up [2].

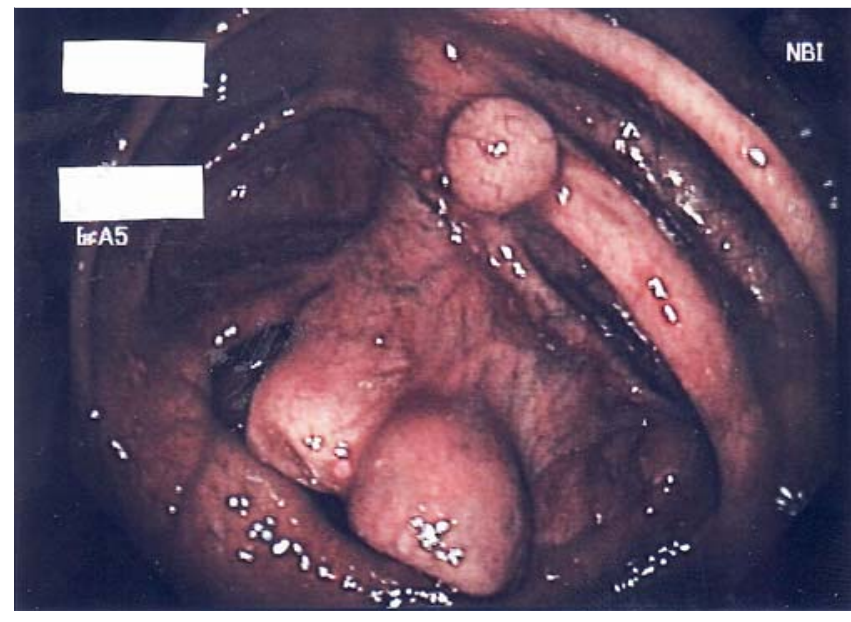

Fig. 1 Narrow-band imaging showed three semi-pedunculated polyps covered by normal mucosa in the ascending colon.

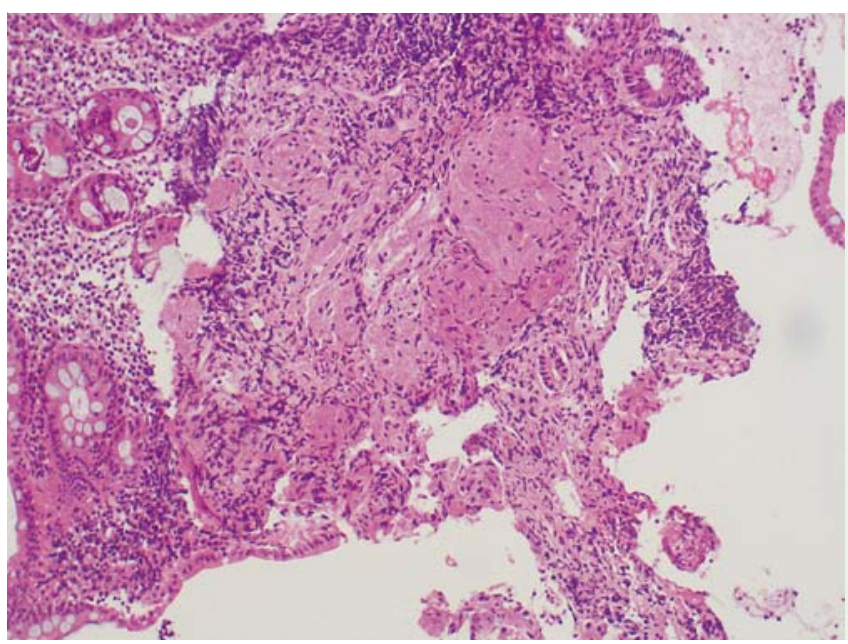

Fig. 2 Histologic examination of the polypectomy specimen showed a submucosal tumor composed of cells with abundant granular cytoplasm. (Hematoxylin and eosin, $\times 50$ ).

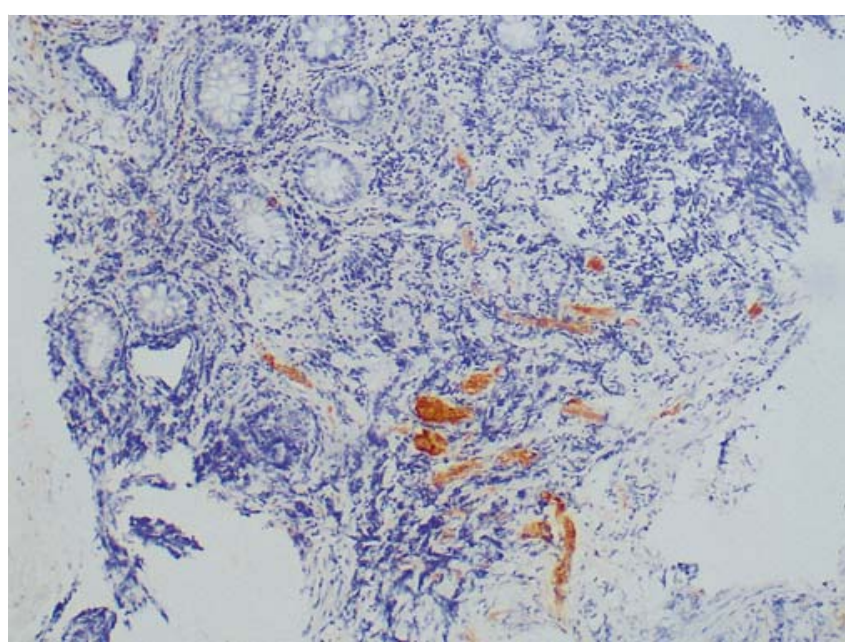

Fig. 3 Immunohistochemical examination for S-100 protein revealed diffuse and strong expression of $\mathrm{S}-100$ protein in tumor cells $(\times 50)$.

\section{Competing interests: None}


J. B. Soares, A. Machado, R. Gonçalves Gastroenterology Department of Braga Hospital, Braga, Portugal

\section{References}

1 Sohn DK, Choi HS, Chang YS et al. Granular cell tumor of the colon: report of a case and review of the literature. World J Gastroenterol 2004; 10: 2452 - 2454

2 Rossi GB, de Bellis M, Marone P et al. Granular cell tumors of the colon: report of a case and review of the literature. J Clin Gastroenterol 2000; 30: 197-199

\section{Bibliography}

DOI $10.1055 / \mathrm{s}-0029-1244140$

Endoscopy 2010; 42: E158-E159

(c) Georg Thieme Verlag KG Stuttgart · New York . ISSN 0013-726X

\section{Corresponding author}

\section{J. B. Soares, MD}

Gastroenterology Department of Braga Hospital Largo Eng. Carlos Amarante

Apartado 2242

4701-965 Braga

Portugal

Fax: +351-253-209092

jbrunosoares@yahoo.com 